http://dx.doi.org/10.11646/zootaxa.3768.5.4

http://zoobank.org/urn:lsid:zoobank.org:pub:38F94125-5B01-46B4-BFAA-71A0D9BCFE73

\title{
A new species of Malayopotamon Bott, 1968 (Crustacea: Decapoda: Brachyura: Potamidae), a freshwater crab from northern Sumatra, Indonesia
}

\author{
PETER K. L. NG
}

Raffles Museum of Biodiversity Research, Department of Biological Sciences, National University of Singapore, Kent Ridge, Singapore 119260, Republic of Singapore.E-mail:dbsngkl@nus.edu.sg

\begin{abstract}
A new species of potamid freshwater crab, Malayopotamon weh sp. nov., is described from the island of Pulau Weh off northern Sumatra, Indonesia. The species superficially resembles three Sumatran species: M. batak Ng \& Wowor, 1991, M. tobaense (Bott, 1968), and M. turgeo $\mathrm{Ng} \& \mathrm{Tan}, 1999$, but can easily be distinguished by various carapace as well as gonopod characters.
\end{abstract}

Key words: Crustacea, Potamidae, taxonomy, Malayopotamon, new species, Sumatra, Indonesia

\section{Introduction}

The potamid genus Malayopotamon Bott, 1968 (type species Telphusa larnaudi brevimarginata De Man, 1892) currently contains 11 species from Sumatra and western Java (Ng et al. 2008; Wowor \& Tan 2010). A recent specimen obtained from the island of Pulau Weh off the northern tip of Sumatra in the Andaman Sea proved to belong to a new species, here named Malayopotamon weh sp. nov.

The type specimen is deposited in the Museum Zoologicum Bogoriense (MZB), Cibinong, Java, Indonesia. Measurements, in millimetres, are of the carapace widths and lengths, respectively. The abbreviations G1 and G2 are used for the male first and second gonopods, respectively. The terminology used follows that in $\mathrm{Ng}$ (1988) and Ng \& Tan (1999).

\section{Systematic account}

Potamidae Ortmann, 1896

Malayopotamon Bott, 1968

Malayopotamon weh sp. nov.

(Figs. 1-4)

Material examined. Holotype: male $(15.5 \times 12.1 \mathrm{~mm})(\mathrm{MZB})$, waterfall, Pulau Weh, $5.82^{\circ} \mathrm{N} 95.28^{\circ} \mathrm{E}, \mathrm{Aceh}$ Province, northern Sumatra, Indonesia, coll. locals, March 2013.

Diagnosis. Carapace with branchial, gastric regions gently convex, not distinctly inflated or swollen (Fig. 2A, $\mathrm{B})$; frontal region with low granules; anterolateral regions with distinct low striae, most of branchial regions almost smooth; epibranchial regions with very low striae; mesogastric, urogastric, cardiac, intestinal regions almost smooth, orbital regions almost smooth (Fig. 2A); epigastric cristae not clearly demarcated, area marked by rows of transverse striae; postorbital cristae distinct but not sharp crest, demarcated by series of strong, adjacently arranged striae (Fig. 2A, B); external orbital tooth broadly triangular, outer margin gently granulated, twice length of inner 
Three other species are known from Aceh Province in northern Sumatra, M. batak, M. tobaense and M. turgeo. Malayopotamon weh sp. nov. can immediately be separated from M. batak by its slightly rugose to smooth gastric and cardiac and frontal regions, which in M. batak, is strongly granular and rugose (see Ng \& Wowor 1991: pl. 1). The G1 of M. batak has a proportionately shorter and more quadrate terminal segment ( $\mathrm{Ng} \&$ Wowor 1991: fig. 1B-E; Ng \& Tan 1999: fig. 2a, b) than in M. weh sp. nov., where the terminal segment is long and cylindrical (Fig. 4A-C). Malayopotamon tobaense can be separated from $M$. weh sp. nov. by the postorbital cristae being confluent with the epibranchial tooth, and the postorbital and epibranchial cristae being more distinct and sharp (see Bott 1970: pl. 58, fig. 89) (postorbital cristae not joining the epibranchial teeth and the postorbital and epigastric cristae not sharp in $M$. weh n. sp.; Fig. 2A, B), and the distal part of the subterminal segment of the G1 is distinctly bent with the terminal segment short and quadrate ( $\mathrm{Ng} \&$ Tan 1999: fig. 6) (distal part of the subterminal segment gently curving and the terminal segment elongated and cylindrical in $M$. weh sp. nov., Fig. 4A-C). Malayopotamon turgeo is distinctive in having the dorsal surface of the carapace convex, giving it a more inflated physiognomy; and its postorbital cristae is also confluent with and joins the epibranchial tooth ( $\mathrm{Ng} \&$ Tan 1999: fig. 7a) (submarginally interrupted in $M$. weh sp. nov., Fig. 2A). The structures of the G1 are also very different. While the terminal segments are both cylindrical, that of $M$. turgeo is gently curving upwards and the distal part of the subdistal segment is strongly bent $(\mathrm{Ng} \&$ Tan 1999: fig. 7c, e), whereas the distal part of the subterminal segment is gently curving and the terminal segment evenly cylindrical in $M$. weh sp. nov. (Fig. 4A-C). In addition, while male thoracic sternites 3 and 4 are completely fused in M. weh sp. nov. (Fig. 3D), there is a shallow but visible groove present between these sternites in M. batak, M. tobaense and M. turgeo (see Bott 1970: pl. 58 fig. 89; Ng \& Wowor 1991: pl. 1; Ng \& Tan 1999: fig. 7b).

The small island of Pulau Weh (ca. $156 \mathrm{~km}^{2}$ ) is relatively isolated, being about $15 \mathrm{~km}$ north of the northernmost tip of Sumatra. Relatively high (about $600 \mathrm{~m}$ in altitude), it has several waterfalls and streams. De Man (1895) reported on some intertidal crabs from the island (see also $\mathrm{Ng} \&$ Liu 1999), but surprisingly, no freshwater decapods have ever been recorded. The present record of a freshwater potamid crab is therefore noteworthy.

\section{Acknowledgements}

The author thanks Daniel Ng for the colour photographs of the species and for passing the specimen to him for study. Helpful comments on the manuscript from Peter Castro (California State Polytechnic University, U.S.A.) and Shy Jhy-Yun (National Penghu Institute of Technology, Taiwan) are much appreciated.

\section{References}

Bott, R. (1970) Die Süßwasserkrabben von Europa, Asien, Australien und ihre Stammesgeschichte. Eine Revision der Potamoidea und der Parathelphusoidea (Crustacea, Decapoda). Abhandlungen der senckenbergischen naturforschenden Gesellschaft, 526, 1-338, figs. 1-8, pls. 1-58, Map 1.

Man, J.G. De (1895) Bericht über die von Herrn Schiffscapitän Storm zu Atjeh, an den westlichen Küsten von Malakka, Borneo und Celebes sowie in der Java-See gesammelten Decapoden und Stomatopoden. Zweiter Theil. Zoologische Jahrbücher, Abteilung für Systematik, Geographie und Biologie der Thiere, 9 (1), 75-218.

Ng, P.K.L. (1988) The Freshwater Crabs of Peninsular Malaysia and Singapore. Department of Zoology, National University of Singapore, Shinglee Press, pp. i-viii, 1-156, figs. 1-63, 4 colour pls.

Ng, P.K.L., Guinot, D. \& Davie, P.J.F. (2008) Systema Brachyurorum: Part I. An annotated checklist of extant brachyuran crabs of the world. Raffles Bulletin of Zoology, Supplement 17, 1-286.

Ng, P.K.L. \& Liu, H.-C. (1999) The taxonomy of Sesarma tangi Rathbun, 1931 and S. stormi De Man, 1895 (Crustacea: Decapoda: Brachyura: Grapsidae: Sesarminae), with establishment of a new genus for S. stormi. Zoological Studies, 38 (2), 228-237.

Ng, P.K.L. \& Tan, S.H. (1999) Revision of the Southeast Asian potamid crabs of the genus Malayopotamon Bott, 1968 (Crustacea: Decapoda: Brachyura). Journal of Natural History, 33 (2), 207-231. http://dx.doi.org/10.1080/002229399300380

Ng, P.K.L. \& Wowor, D. (1991) A new species of Malayopotamon Bott, 1968 (Crustacea: Decapoda: Brachyura: Potamidae) from northern Sumatra. Treubia, 30 (2), 165-170.

Wowor, D. \& Tan, S.H. (2010) Description of a new species of Malayopotamon Bott, 1968 (Decapoda, Brachyura, Potamidae) from Gunung Slamet, Central Java, Indonesia. Studies on Malacostraca: Lipke Bijdeley Holthuis Memorial Volume. Fransen, C.H.J.M., De Grave, S. \& Ng, P.K.L. (Eds.), Crustaceana Monographs, 14, 727-734. http://dx.doi.org/10.1163/9789047427759_054 